\title{
HUBUNGAN ANTARA KONDISI FISIK RUMAH DAN PERILAKU PENDERITA DENGAN KEJADIAN MALARIA DI WILAYAH KERJA PUSKESMAS BANJARMANGU 1 KABUPATEN BANJARNEGARA TAHUN 2016
}

\author{
Afra Wayranu' ${ }^{1)}$, Lagiono ${ }^{2)}$, Marsum $^{3)}$ \\ Jurusan Kesehatan Lingkungan, Politeknik Kesehatan Kemenkes Semarang, \\ Jl.Raya Baturaden KM 12 Purwokerto, Indonesia
}

\begin{abstract}
Abstrak
Malaria merupakan penyakit yang disebabkan oleh penyakit yang di sebabkanolehparasitdari genus Plasmodium yang termasukgolongan protozoa melaluiperantaratusukan (gigitan) serangganyamukAnopheles spp. Puskesmas 1 Banjarmangu merupakan daerah dengan jumlah kasus Malaria tertinggi di wilayah Kabupaten Banjarnegara, pada tahun 2015 berjumlah 99 kasus. Tujuan penelitian ini adalah untuk mengetahui hubungan lingkungan fisik rumah dan perilaku penderita dengan kejadian Malaria di Kabupaten Banjarnegara.

Metode penelitian ini adalah penelitian analitik observasional dengan desain studi Case Control, jumlah sampel kasus sejumlah 75 kasus dan 75 kontrol. Variabel yang diteliti meliputi keberadaan ventilasi, kawat kasa, langit-langit rumah, semak-semak, parit/selokan, kandang ternak, genangan air, keadaan dinding rumah kebiasaan menggunakan kelambu, kebiasaan menggunakan obat nyamuk, keluar rumah malam hari. Analisis yang digunakan yaitu Data yang diperoleh dianalisis ke dalam analisis univariat, bivariat dengan uji Chi-square $\left(X^{2}\right)$ dan multivariat dengan menggunakan uji regresi logistik.

Hasil analisis bivariat menunjukkan variabel yang berhubungan dengan kejadian Malaria yaitu variabel keberadaan kawat kasa $(p=0,011 ; O R=4,103)$, langit-langit $(p=0,000 ; O R=9,333)$, semak-semak $(p=0,000 ;$ OR $=21,673)$, parit/selokan $(p=0,000 ;$ OR $=42,667)$, kebiasaan menggunakan obat nyamuk $(p=0,000 ;$ OR $=9,333)$, kebiasaan keluar rumah malam hari $(p=0,000 ;$ OR =9,073), keberadaan genangan air $(p=0,014 ;$ OR $=3,632)$. Hasil analisis multivariat diketahui variabel yang berpengaruh besar/ dominan berhubungan dengan kejadian penyakit Malaria adalah variabel keberadaan semak-semak di sekitar rumah $(p=0,011 ;$ OR $=3,980)$.

Simpulan penelitian ini adalah variabel yang berhubungan dengan kejadian Malaria yaitu variabel keberadaan kawat kasa, langit-langit rumah, semak-semak, parit/selokan, kebiasaan menggunakan obat nyamuk, kebiasaan keluar rumah malam hari, dan keberadaan genangan air. Variabel yang berpengaruh dominan adalah variabel keberadaan semak-semak. Disarankan bagi pihak puskesmas 1 Banjarmangu dan kader kesehatan untuk meningkatkan promosi kesehatan kepada masyarakat tentang cara mencegah Malaria .
\end{abstract}

Kata Kunci : : Lingkungan, perilaku, Malaria

\begin{abstract}
Malaria is a disease caused by parasite from Plasmodium genus which is included to protozoa through bite mediator Anopheles sppmosquito. Malaria cases in Banjarnegara Regency in 2015 were 261 cases. Puskesmas 1 Banjarmangu is the place which has the highest cases in BanjarnegaraRegency, in 2015 there were 99 cases. The purpose of this research is to find out the correlation between houses' physical condition and patients' behavior with Malaria case in Banjarnegara Regency.

The method used in this research is observational analytic with Case Control study design, the amount of sample was 75 cases and 75 controls. The variable examined were the existence of ventilation, wire gauze, ceiling, bush, sewerage, pet house, puddle of water, wall condition, the habit of using mosquito net, the habit of using mosquito essence, the habit of going out at night. The analysis used is data which was obtained then analyzed into univariate analysis, bivariate used Chi-square $\left(X^{2}\right)$ test and multivariate used logistic regression test.

The result bivariate shows that variable correlated with Malaria case was the existence of wire gauze variable $p=0,011 ;$ OR $=4,103)$, ceiling $(p=0,000 ;$ OR =9,333), bush $(p=0,000 ;$ OR $=21,673)$, sewerage $(p=0,000 ;$ OR
\end{abstract}


$=42,667)$, the habit of using mosquito essence ( $p=0,000 ;$ OR =9,333), the habit of going out at night ( $p=0,000 ;$ OR $=9,073)$, puddle of water $(p=0,014 ; O R=3,632)$. The result of multivariate shows that the biggest influence/dominant variable correlated with Malaria case was the existence of bush around the house variable $(p=$ 0,$011 ; O R=3,980$ ).

The conclusion of this research is variable correlated with Malaria case were the existence of ventilation, wire gauze, ceiling, bush, sewerage, pet house, puddle of water, wall condition, the habit of using mosquito net, the habit of using mosquito essence, the habit of going out at night. The dominant variable in this research was bush around the house. The researcher suggests to Puskemas 1 Banjarmangu officials and health cadres to improve health promotion to society about how to prevent Malaria.

Key Words : Environment, Behavior, Malaria

1) E-mail: afra_wayranu@yahoo.co.id

2) E-mail: lagionoabdulwahid@yahoo.co.id

3) E-mail: marsumrahma@gmail.com 


\section{Pendahuluan}

Malaria masih merupakan salah satu masalah kesehatan masyarakat yang dapat menyebabkan kematian terutama pada kelompok risiko tinggi, yaitu bayi, anak balita dan ibu hamil. Malaria secara langsung juga menyebabkan anemia dan menurunkan produktivitas kerja serta memberikan dampak negatif terhadap pariwisata. Setiap tahun lebih dari 300 juta penduduk dunia terinfeksi malaria dan 2-3 juta orang meninggal dunia (Kemenkes, 2011).

Faktor resiko kejadian malaria merupakan kondisi fisik rumah, lingkungan fisik, dan perilaku. Kondisi fisik rumah berkaitan sekali dengan kejadian malaria, terutama yang berkaitan dengan mudah atau tidaknya nyamuk masuk ke dalam rumah, ventilasi yang tidak di pasang kawat kasa dapat mempermudah nyamuk masuk kedalam rumah. Langit-langit atau pembatas ruangan dinding bagian atas dengan atap yang terbuat dari kayu, internit maupun anyaman bambu halus sebagai penghalang masuknya nyamuk ke dalam rumah dilihat dari ada tidaknya langit-langit pada semua atau sebagian ruangan rumah. Kualitas dinding yang tidak rapat jika dinding rumah terbuat dari anyaman bambu kasar ataupun kayu/papan yang terdapat lubang lebih dari $1,5 \mathrm{~mm}^{2}$ akan mempermudah nyamuk masuk ke dalam rumah ( Darmadi, 2002 ). Lingkungan fisik yang diperhatikan dalam kejadian malaria, jarak rumah dari tempat istirahat dan tempat perindukan yang disenangi nyamuk Anopheles seperti adanya semak yang rimbun akan menghalangi sinar matahari menembus permukaan tanah, sehingga adanya semak-semak yang rimbun berakibat lingkungan menjadi teduh serta lembab dan keadaan ini merupakan tempat istirahat yang disenangi nyamuk Anopheles, parit atau selokan yang digunakan untuk pembuangan air merupakan tempat berkembang biak yang disenangi nyamuk, dan kandang ternak sebagai tempat istirahat nyamuk sehingga jumlah populasi nyamuk di sekitar rumah bertambah. Faktor risiko perilaku terdiri praktek kebiasaan sehari-hari seperti kebiasaan menggunakan kelambu, kebiasaan menggunakan obat anti nyamuk, kebiasaan keluar rumah malam hari. ( Handayani dkk, 2008).

Kejadian Malaria di Kabupaten Banjarnegara cukup tinggi. Penyakit malaria seluruhnya pada tahun 2014 yang tercatat ada 286 kasus, dan pada tahun 2015 tercatat ada 261 kasus. Sedangkan kejadian malaria di Wilayah Kerja Puskesmas 1 Banjarmangu pada tahun 2014 sebanyak 100 kasus, tahun 2015 periode Januari September sebanyak 75 kasus. ( DKK Banjarnegara, 2015 ).

Tujuan dari penelitian ini adalah untuk mengetahui hubungan antara kondisi fisik rumah dan perilaku penderita dengan kejadian malaria di Wilayah Kerja
Puskesmas 1 Banjarmangu Kabupaten Banjarnegara tahun 2016.

\section{Bahan dan Metode}

Metode penelitian ini adalah penelitian analitik observasional dengan desain studi Case Control, jumlah sampel kasus sejumlah 75 kasus dan 75kontrol, total minimal adalah 150 sampel. Variabel yang diteliti meliputi kawat kasa pada ventilasi rumah, langit-langit rumah, kerapatan dinding, semak-semak, parit atau selokan di sekitar rumah, kandang ternak di sekitar rumah, genangan air di sekitar rumah, kebiasaan menggunakan kelambu, kebiasaan penggunaan obat nyamuk dan kebiasaan keluar rumah malam hari.

\section{Hasil dan Pembahasan \\ Gambaran Umum Wilayah}

Puskesmas Banjarmangu 1 merupakan salah satu Puskesmas di Kabupaten Banjarnegara yang letaknya berada pada jarak $7 \mathrm{~km}$ ke arah utara dari Ibu Kota Kabupaten. Secara Astronomi terletak diantara 7.358014 Lintang Selatan dan 109.690317 Bujur Timur. Dibatasi oleh 4 Wilayah kerja Puskesmas yaitu : di sebelah Utara Puskesmas Banjarmangu 2, Timur Puskesmas Madukara 2, Selatan Puskesmas Bawang 1 dan Puskesmas Wanadadi 2 dan Barat Puskesmas Wanadadi 1. Dengan luas wilayah $\pm 2.200,300 \mathrm{Ha}$ atau sekitar 2,06 \% dari Luas Wilayah Kabupaten Banjarnegara (106.970,997 Ha). Wilayah Puskesmas Banjarmangu 1 terdiri dari 9 Desa. Berdasarkan data dari Kecamatan Banjarmangu pada akhir tahun 2015, Jumlah penduduk di wilayah Puskesmas 1 Banjarmangu sebanyak 24.266 jiwa yang terdiri dari 12.338 laki-laki dan 11.928 perempuan.

Berdasarkan data dari Puskesmas 1 Banjarmangu pada akhir tahun 2015, jumlah penduduk di wilayah Puskesmas 1 Banjarmangu dengan Malaria terbanyak yaitu desa Paseh dengan 70 kasus, desa Sigeblog 26 kasus, desa Pekandangan 3 kasus, dan 6 desa lainnya tidak ada kasus Malaria.

\section{Univariat}

\section{Keberadaan Kawat Kasa pada Ventilasi}

Rumah responden yang ditemukan tidak ada kawat kasa pada ventilasi sebanyak 70 rumah $(93,3 \%)$ dan yang ada kawat kasa pada ventilasi rumah sebanyak 5 rumah $(6,7 \%)$. Pada kelompok kontrol rumah responden yang ditemukan tidak ada kawat kasa sebanyak 58 rumah $(77,3 \%)$ dan yang ada kawat kasa sebanyak 17 rumah $(22,7 \%)$.

\section{Keberadaan Langit-Langit}

Rumah responden yang ditemukan tidak ada langit-langit rumah sebanyak 70 rumah $(93,3 \%)$ dan yang ada langit-langit rumah sebanyak 5 rumah $(6,7 \%)$. Pada kelompok kontrol rumah responden yang 
ditemukan tidak ada langit-langit sebanyak 45 rumah $(60,0 \%)$ dan yang ada langit-langit sebanyak 30 rumah $(40,0 \%)$.

\section{Keadaan Dinding Rumah}

Rumah responden yang ditemukan keadaan dinding tidak rapat sebanyak 40 rumah $(53,3 \%)$ dan yang keadaan dindingnya rapat sebanyak 35 rumah (46,7\%). Pada kelompok kontrol rumah responden yang ditemukan keadaan dinding tidak rapat sebanyak 43 rumah $(57,3 \%)$ dan yang keadaan dindingnya rapat sebanyak 32 rumah $(42,7 \%)$.

\section{Keberadaan Semak-Semak}

Rumah responden yang ditemukan ada semaksemak di sekitar rumah sebanyak 69 rumah $(92,0 \%)$ dan yang tidak ada semak-semak sebanyak 6 rumah $(8,0 \%)$. Pada kelompok kontrol rumah responden yang ditemukan ada semak-semak sebanyak 26 rumah $(34,7 \%)$ dan yang tidak ada semak-semak sebanyak 49 rumah $(65,3 \%)$.

\section{Keberadaan Parit/Selokan}

Rumah responden yang ditemukan ada parit/selokan di sekitar rumah sebanyak 72 rumah $(96,0 \%)$ dan yang tidak ada parit/selokan sebanyak 3 rumah (4,0\%). Pada kelompok kontrol rumah responden yang ditemukan ada parit/selokan sebanyak 27 rumah $(36,0 \%)$ dan yang tidak ada parit/selokan sebanyak 48 rumah $(64,0 \%)$.

\section{Keberadaan Kandang Ternak}

Rumah responden yang ditemukan ada kandang ternak di sekitar rumah sebanyak 45 rumah $(60,0 \%)$ dan yang tidak ada kandang ternak sebanyak 30 rumah (40,0\%). Pada kelompok kontrol rumah responden yang ditemukan ada kandang ternak sebanyak 48 rumah $(64,0 \%)$ dan yang tidak ada kandang ternak sebanyak 27 rumah $(36,0 \%)$.

\section{Kebiasaan Menggunakan Kelambu}

Rumah responden yang ditemukan tidak menggunakan kelambu sebanyak 33 rumah (44,0\%) dan yang menggunakan kelambu sebanyak 42 rumah $(56,0 \%)$. Pada kelompok kontrol rumah responden yang ditemukan tidak menggunakan kelambu $\mathrm{k}$ sebanyak 45 rumah $(60,0 \%)$ dan yang menggunakan kelambu sebanyak 30 rumah $(40,0 \%)$.

\section{Kebiasaan Menggunakan Obat Nyamuk}

Rumah responden yang ditemukan tidak menggunakan obat nyamuk sebanyak 70 rumah $(93,3 \%)$ dan yang menggunakan obat nyamuk sebanyak 5 rumah $(6,7 \%)$. Pada kelompok kontrol rumah responden yang ditemukan tidak menggunakan obat nyamuk sebanyak 45 rumah $(60,0 \%)$ dan yang menggunakan obat nyamuk sebanyak 30rumah $(40,0 \%)$.

\section{Kebiasaan Keluar Rumah Malam Hari}

Rumah responden yang ditemukan biasa keluar rumah malam hari sebanyak 8 rumah $(10,7 \%)$ dan yang tidak biasa keluar rumah malam hari 67 rumah $(89,3 \%)$. Pada kelompok kontrol rumah responden yang ditemukan biasa keluar rumah malam hari sebanyak 39 rumah $(52,0 \%)$ dan yang tidak biasa keluar rumah malam hari sebanyak 36 rumah (48,0\%).

\section{Keberadaan Genangan Air}

Rumah responden yang ditemukan ada genangan air di sekitar rumah sebanyak 69 rumah $(92,0 \%)$ dan yang tidak ada genangan air6 rumah $(8,0 \%)$. Pada kelompok kontrol rumah responden yang ditemukan ada genangan air sebanyak 57 rumah $(76,0 \%)$ dan yang tidak ada genangan air sebanyak 18 rumah $(24,0 \%)$.

\section{Bivariat}

Hubungan Keberadaan Kawat Kasa dengan kejadian Malaria di Wilayah Kerja Puskesmas 1 Banjarmangu Tahun 2016

Hasil uji statistik dengan menggunakan Chisquare, diperoleh $p$ value 0,011 , karena $p$ value $<0,05$ maka Ho ditolak, artinya ada hubungan yang signifikan antara variabel keberadaan kawat kasa dengan kejadian Malaria di Wilayah Kerja Puskesmas 1 Banjarmangu Kabupaten Banjarnegara Tahun 2016. Nilai Odd Ratio $(O R)=4,103(95 \%$ CI $=1,427-$ 11,798), menunjukan bahwa rumah responden yang tidak ada kawat kasa mempunyai risiko 4,103 kali lebih besar menderita Malaria dari pada rumah responden yang ada kawat kasa.

Penelitian ini sama dengan penelitian Kukuh Purwo Saputro (2013) di Desa Kendaga Kecamatan Banjarmangu Kabupaten Banjarnegara, menyatakan bahwa terdapat hubungan antara pemasangan kasa pada ventilasi dengan kejadian malaria di Desa Kendaga. Hasil perhitungan Odd Ratio (OR) dengan taraf kepercayaan (CI) 95\% (tingkat kemaknaan $\alpha=0,05$ ) diperoleh nilai $\mathrm{OR}=3,600$ (95\% CI $=1,142-11,346)$ menunjukan bahwa ventilasi yang tidak terpasang kasa mempunyai risiko kejadian malaria 3,600 kali dibanding rumah yang ventilasinya terpasang kasa.

Sesuai dengan teori Lestari (2007), adanya kejadian malaria disebabkan rumah yang tidak terpasang kawat kasa akan mempermudah masuknya nyamuk ke dalam rumah. Kawat kasa merupakan penghalang bila kawat kasa dalam keadaan baik.

\section{Hubungan Keberadaan Langit-Langit Rumahdengan kejadian Malaria di Wilayah Kerja Puskesmas 1 Banjarmangu Tahun 2016}

Hasil uji statistik dengan menggunakan Chisquare, diperoleh $p$ value 0,000 , karena $p$ value $<0,05$ maka Ho ditolak, artinya ada hubungan yang signifikan antara variabel keberadaan langit-langit rumah dengan kejadian Malaria di Wilayah Kerja Puskesmas 1 Banjarmangu Kabupaten Banjarnegara Tahun 2016. Nilai Odd Ratio $(O R)=9,333(95 \% \mathrm{CI}=$ $3,372-25,835)$, menunjukan bahwa rumah responden 
yang tidak ada langit-langirt mempunyai risiko 9,333 kali lebih besar menderita Malaria dari pada rumah responden yang ada langit-langit rumah. Hal ini disebabkan rumah yang seluruh ruangannya tidak diberi langit-langit akan mempermudah masuknya nyamuk ke dalam rumah. Seharusnya Puskesmas memberikan penyuluhan guna meningkatkan pengetahuan masyarakat akan pentingnya memasang langit-langit rumah sebagai salah satu usaha dalam rangka mengurangi masuknya nyamuk kedalam rumah responden sehingga dapat terhindar dari gigitan nyamuk.

Menurut Depkes RI (1999), Langit-langit merupakan pembatas ruangan dinding bagian atas dengan atap yang terbuat dari kayu, internit maupun anyaman bambu halus. Jika tidak ada langit-langit berarti ada lobang atau celah antara dinding dengan atap sehingga nyamuk lebih leluasa masuk ke dalam rumah. Dengan demikian risiko untuk kontak antara penghuni rumah dengan nyamuk Anopheles lebih besar dibanding dengan rumah yang ada langit-langitnya.

Penelitian ini sama denga penelitian Darmadi (2002) di Desa Buaran Kecamatan Mayong Kabupaten Jepara menunjukkan bahwa kondisi rumah yang seluruh ruangannya tidak diberi langit-langit mempunyai kecenderungan untuk terjadinya penyakit malaria dengan p (value) $=0,014$ dan nilai Odd Ratio $(O R)=2,39$.

\section{Hubungan Keadaan Dinding Rumahdengan kejadian Malaria di Wilayah Kerja Puskesmas 1 Banjarmangu Tahun 2016}

Hasil uji statistik dengan menggunakan Chisquare, diperoleh $p$ value 0,743 , karena $p$ value $>0,05$ maka Ho diterima, artinya tidak ada hubungan yang signifikan antara variabel keadaan dinding rumah dengan kejadian Malaria di Wilayah Kerja Puskesmas 1 Banjarmangu Kabupaten Banjarnegara Tahun 2016. Nilai Odd Ratio $(O R)=0,850(95 \%$ CI =0,447- 1,620), menunjukan bahwa rumah responden yang keadaan dindingnya tidak rapat mempunyai risiko 0,850 kali lebih besar menderita Malaria dari pada rumah responden yang keadaan dindingnya rapat.

Penelitian ini tidak sama dengan penelitian Aprilia Ayu Pamela (2009) hasil analisis statistik melalui uji chi square menunjukkan bahwa ada hubungan antara dinding rumah dengan kejadian malaria di Desa Ketosari Kecamatan Bener Kabupaten Purworejo pada $\alpha=0,05$ dengan $\mathrm{p}$ (value) $=0,013$. Besar hubungan tersebut dari hasil odds ratio diperoleh angka sebesar 5,00 berarti keluarga yang tinggal di rumah dengan kondisi dinding yang tidak rapat mempunyai risiko untuk terjadinya penyakit malaria 5 kali dibanding dengan keluarga yang tinggal di rumah dengan kondisi yang rapat.
Menurut Handayani dkk, (2008) dinding rumah responden yang terbuat dari pasang batu bata maupun yang terbuat dari anyaman bambu ataupun kayu terdapat lubang lebih dari $1,5 \mathrm{~mm}^{2}$. Keadaan dinding yang demikian akan mempermudah masuknya nyamuk ke dalam rumah lebih besar bila dibandingkan dengan kondisi dinding rumah yang rapat. Kondisi tersebut menyebabakan penghuni rumah lebih potensial digigit nyamuk Anopheles, karena nyamuk lebih leluasa masuk ke dalam rumah, sehingga akan memperbesar risiko terjadinya penularan penyakit malaria

Hubungan Keberadaan Semak-Semak di Sekitar Rumahdengan kejadian Malaria di Wilayah Kerja Puskesmas 1 Banjarmangu Tahun 2016

Hasil uji statistik dengan menggunakan Chisquare, diperoleh $p$ value 0,000 , karena $p$ value $<0,05$ maka Ho diterima, artinya ada hubungan yang signifikan antara variabel keberadaan semak-semak di sekitar rumah responden dengan kejadian Malaria di Wilayah Kerja Puskesmas 1 Banjarmangu Kabupaten Banjarnegara Tahun 2016. Nilai Odd Ratio $(O R)=$ 21,673 (95\% CI = 8,296 - 56,617), menunjukan bahwa rumah responden yang terdapat semak-semak di sekitar rumah mempunyai risiko 21,673 kali lebih besar menderita Malaria dari pada rumah responden yang tidak ada semak-semak di sekitar rumah.

Menurut Lestari dkk, (2007), keberadaan semaksemak yang rimbun akan menghalangi sinar matahari menembus permukaan tanah, sehingga adanya semaksemak yang rimbun berakibat lingkungan menjadi teduh serta lembab dan keadaan ini merupakan tempat istirahat yang disenangi nyamuk Anopheles, sehingga jumlah populasi nyamuk di sekitar rumah bertambah dan menyebabkan keluarga yang tinggal di rumah yang terdapat semak di sekitarnya mempunyai risiko untuk terjadi penularan penyakit malaria dibanding dengan keluarga yang tinggal di rumah tidak ada semak-semak di sekitarnya.

Penelitian ini sama dengan penelitian Yis Romadhon (2001) di Kecamatan Salaman Magelang menunjukkan bahwa proporsi rumah yang ada semaksemak rimbun mempunyai kecenderungan untuk terjadinya penyakit malaria dengan $\mathrm{p}($ value $)=0,001$.

Hubungan Keberadaan Parit/Selokan di Sekitar Rumahdengan kejadian Malaria di Wilayah Kerja Puskesmas 1 Banjarmangu Tahun 2016

Hasil uji statistik dengan menggunakan Chisquare, diperoleh $p$ value 0,000 , karena $p$ value $<0,05$ maka Ho diterima, artinya ada hubungan yang signifikan antara variabel keberadaan parit/selokan di sekitar rumah responden dengan kejadian Malaria di Wilayah Kerja Puskesmas 1 Banjarmangu Kabupaten Banjarnegara Tahun 2016. Nilai Odd Ratio $(O R)=$ 42,667 (95\% CI $=12,255-148,543)$, menunjukan bahwa rumah responden yang terdapat parit/selokan di 
sekitar rumah mempunyai risiko 42,667 kali lebih besar menderita Malaria dari pada rumah responden yang tidak ada parit/selokan di sekitar rumah.

Penelitian ini sama dengan penelitian Pamela (2009), di Desa Ketosari Kecamatan Bener Kabupaten Purworejo menunjukan bahwa hasil analisis statistik melalui uji chi square menunjukkan bahwa ada hubungan antara parit atau selokan dengan kejadian malaria di Desa Ketosari Kecamatan Bener Kabupaten Purworejo pada $\alpha=0,05$ dengan $p$ (value) $=0,000$. Besar hubungan tersebut dari hasil odds ratio diperoleh angka sebesar 0,06 berarti keluarga yang tinggal di rumah dengan kondisi terdapat parit atau selokan di sekitar rumah mempunyai risiko untuk terjadinya penyakit malaria 0,06 kali dibanding dengan keluarga yang tinggal di rumah dengan kondisi tidak terdapat parit atau selokan di sekitar rumah.

Menurut Handayani dkk, (2008), saluran air yang digunakan untuk pembuangan air hujan, limbah rumah tangga menggenang dan dapat digunakan sebagai tempat berkembang biak nyamuk. Nyamuk betina akan bertelur di dalam air yang tergenang. Telur-telur ini akan berkembang menjadi larva dan kemudian berubah menjadi bentuk dewasa dalam 10 hari. Sehingga jumlah populasi nyamuk di sekitar rumah bertambah dan menyebabkan keluarga yang tinggal di rumah yang terdapat parit/selokan di sekitar rumah mempunyai risiko untuk terjadi penularan penyakit malaria dibanding dengan keluarga yang tinggal di rumah yang tidak ada parit/selokan di sekitarnya.

Hubungan Keberadaan Kandang Ternak di Sekitar Rumahdengan kejadian Malaria di Wilayah Kerja Puskesmas 1 Banjarmangu Tahun 2016

Hasil uji statistik dengan menggunakan Chisquare, diperoleh $p$ value 0,737 , karena $p$ value $>0,05$ maka Ho ditolak, artinya tidakada hubungan yang signifikan antara variabel keberadaan kandang ternak di sekitar rumah responden dengan kejadian Malaria di Wilayah Kerja Puskesmas 1 Banjarmangu Kabupaten Banjarnegara Tahun 2016. Nilai Odd Ratio $(O R)=$ $0,844(95 \%$ CI $=0,436-1,633)$, menunjukan bahwa rumah responden yang terdapat kandang ternak di sekitar rumah mempunyai risiko 0,844 kali lebih besar menderita Malaria dari pada rumah responden yang tidak ada kandang ternak di sekitar rumah.

Penelitian ini tidak sama dengan penelitian Aprilia Ayu Pamela (2009), hasil analisis statistik melalui uji chi square menunjukkan bahwa ada hubungan antara kandang ternak dengan kejadian malaria di Desa Ketosari Kecamatan Bener Kabupaten Purworejo pada $\alpha=0,05$ dengan $\mathrm{p}$ (value) $=0,000$. Besar hubungan tersebut dari hasil odds ratio diperoleh angka sebesar 0,01 berarti keluarga yang tinggal di rumah dengan kondisi 65 terdapat kandang ternak di sekitar rumah mempunyai risiko untuk terjadinya penyakit malaria
0,01 kali dibanding dengan keluarga yang tinggal di rumah dengan kondisi tidak terdapat kandang ternak di sekitar rumah.

Menurut Boesri dkk, (2003), kondisi bangunan yang dipergunakan sebagai tempat memelihara ternak seperti sapi, kerbau maupun kambing di Desa Ketosari pada umumnya bersebelahan dengan rumah, hanya dipisahkan dengan dinding. Dilihat dari bionomik nyamuk Anopheles di daerah Ketosari bahwa pada siang hari Anopheles maculatus dan Anopheles balabacensis ditemukan istirahat di kandang ternak seperti sapi, kerbau maupun kambing. Sehingga akan menambah kepadatan nyamuk di sekitar rumah dan keluarga yang tinggal di rumah tersebut mempunyai risiko untuk terjadi penularan penyakit malaria dibanding dengan keluarga yang tinggal di rumah yang tidak ada kandang ternak atau keluarga yang menempatkan kandangnya jauh dari rumah.

Hubungan Kebiasaan Menggunakan Kelambu dengan kejadian Malaria di Wilayah Kerja Puskesmas 1 Banjarmangu Tahun 2016

Hasil uji statistik dengan menggunakan Chisquare, diperoleh $p$ value 0,072 , karena $p$ value $>0,05$ maka Ho ditolak, artinya tidak ada hubungan yang signifikan antara variabel kebiasaan responden menggunakan kelambu dengan kejadian Malaria di Wilayah Kerja Puskesmas 1 Banjarmangu Kabupaten Banjarnegara Tahun 2016. Nilai Odd Ratio $(O R)=$ $0,542(95 \% \mathrm{CI}=0,274-1,002)$, menunjukkan bahwa responden yang menggunakan kelambu mempunyai risiko 0,542 kali lebih besar menderita Malaria dari pada responden yang tidak menggunakan kelambu.

Penelitian ini tidak sama dengan penelitian Ika Nur Atikoh (2015), hasil uji statistik dengan menggunakan Chi-square, diperoleh $\mathrm{p}$ value 0,000 , karena $\mathrm{p}$ value < 0,05 maka Ho diterima, artinya ada hubungan yang signifikan antara variabel kebiasaan menggunakan kelambu dengan kejadian Malaria di. Hasil penelitian ini dapat dipengaruhi berbagai hal, antara lain ialah apakah kelambu yang dipakai merupakan kelambu berinsektisida atau tidak.

Hubungan Kebiasaan Menggunakan Obat Nyamuk dengan kejadian Malaria di Wilayah Kerja Puskesmas 1 Banjarmangu Tahun 2016

Hasil uji statistik dengan menggunakan Chisquare, diperoleh $p$ value 0,000 , karena $p$ value $<0,05$ maka Ho diterima, artinya ada hubungan yang signifikan antara variabel kebiasaan responden menggunakan obat nyamuk dengan kejadian Malaria di Wilayah Kerja Puskesmas 1 Banjarmangu Kabupaten Banjarnegara Tahun 2016. Nilai Odd Ratio $(O R)=$ 9,333 (95\% CI = 3,372- 25,835), menunjukan bahwa responden yang menggunakan obat nyamuk mempunyai risiko 9,333 kali lebih besar menderita 
Malaria dari pada responden yang tidak menggunakan obat nyamuk.

Penelitian ini sama dengan penelitian Marcly L, dkk (2012), yang menyatakan bahwa terdapat hubungan yang bermakna antara penggunaan bahan anti nyamuk dengan kejadian malaria di wilayah kerja Puskesmas Remu Kota Sorong dengan p value sebesar 0,009 dan nilai OR sebesar 3,281 (95\% CI= 1,3368,058). Berdasarkan hasil wawancara dengan responden bahwa banyak responden yang tidak menyukai bau dari bahan anti nyamuk tersebut dan dilihat dari kurangnya kesadaran masyarakat tentang bahaya malaria sehingga menganggap bahwa malaria bukan penyakit yang berbahaya sehingga penggunaan bahan anti nyamuk sangatlah tidak penting untuk digunakan.

Hubungan Kebiasaan Keluar Rumah Malam Hari dengan kejadian Malaria di Wilayah Kerja Puskesmas 1 Banjarmangu Tahun 2016

Hasil uji statistik dengan menggunakan Chisquare, diperoleh $p$ value 0,000 , karena $p$ value $<0,05$ maka Ho diterima, artinya ada hubungan yang signifikan antara variabel kebiasaan responden keluar rumah malam hari dengan kejadian Malaria di Wilayah Kerja Puskesmas 1 Banjarmangu Kabupaten Banjarnegara Tahun 2016. Nilai Odd Ratio $(O R)=$ 9,073 (95\% CI = 3,832 - 21,480), menunjukkan bahwa responden yang mempunyai kebiasaan keluar rumah malam hari mempunyai risiko 9,073 kali lebih besar menderita Malaria dari pada responden yang tidak mempunyai kebiasaan keluar rumah malam hari.

Penelitian ini tidak sama dengan penelitian Kukuh Purwo Saputro (2013), yang menyatakan bahwa tidak ada hubungan antara kebiasaan keluar rumah pada malam hari dengan kejadian malaria di Desa Kendaga. Tidak ada hubungan antara kebiasaan keluar rumah pada malam hari dengan kejadian malaria pada penelitian ini disebabkan karena ada kesetaraan jumlah yang memiliki riwayat kebiasaan keluar rumah pada malam hari antara kelompok kasus dan kontrol, walaupun secara statistik proporsi kebiasaan keluar rumah pada malam hari untuk kelompok kasus 42,31\% lebih besar dari persentase kelompok kontrol 26,92\% dimana kelompok kasus lebih berisiko untuk terkena gigitan nyamuk malaria karena dilihat dari bionomik vektornya nyamuk Anopheles lebih sering berada diluar rumah.

Menurut Lestari (2007), nyamuk Anopheles paling aktif mencari darah pukul 21.00-03.00 dan menurut Darmadi (2002), kebiasaan penduduk berada di luar rumah pada malam hari antara pukul $21.00 \mathrm{~s} / \mathrm{d} 22.00$ berhubungan erat dengan kejadian malaria, karena frekuensi mengisap darah jam tersebut tinggi.
Hubungan Keberadaan Genangan Air di Sekitar Rumah dengan kejadian Malaria di Wilayah Kerja Puskesmas 1 Banjarmangu Tahun 2016

Hasil uji statistik dengan menggunakan Chisquare, diperoleh $p$ value 0,014 , karena $p$ value $<0,05$ maka Ho diterima, artinya ada hubungan yang signifikan antara variabel keberadaan genangan air di sekitar rumah dengan kejadian Malaria di Wilayah Kerja Puskesmas 1 Banjarmangu Kabupaten Banjarnegara Tahun 2016. Nilai Odd Ratio $(O R)=$ $3,632(95 \% \mathrm{CI}=1,352-9,757)$, menunjukan bahwa rumah responden yang terdapat genangan air di sekitar rumah mempunyai risiko 3,632 kali lebih besar menderita Malaria dari pada rumah responden yang tidak ada genangan air di sekitar rumah.

Menurut Prabowo (2004), keadaan lingkungan berpengaruh besar terhadap ada tidaknya malaria di suatu daerah. Adanya danau air payau, genangan air di hutan, pesawahan, tambak ikan, pembukaan hutan dan pertambangan di suatu daerah akan meningkatkan kemungkinan timbulnya penyakit malaria karena tempat-tempat tersebut merupakan tempat perindukan nyamuk malaria.

Penelitian ini sama dengan penelitian Kukuh Purwo Saputro (2013), yang menyatakan bahwa terdapat hubungan antara keberadaan genangan air di sekitar rumah dengan kejadian malaria di Desa Kendaga. Hasil perhitungan Odd Ratio (OR) dengan taraf kepercayaan (CI) 95\% (tingkat kemaknaan $\alpha=$ $0,05)$ diperoleh nilai $\mathrm{OR}=4,250(95 \% \mathrm{CI}=1,332$ 13,562) menunjukan bahwa adanya genangan air disekitar rumah mempunyai risiko kejadian malaria 4,250 kali dibanding rumah yang tidak terdapat genangan air.Kondisi lingkungan di Desa Kendaga memang mendukung untuk tempat perindukan nyamuk Anopheles, dari hasil penelitian di lapangan menunjukan $51,92 \%$ responden ditemukan parit/selokan yang dapat menampung genangan air di sekitar rumah, berupa parit/selokan limbah rumah tanggamaupun genangan air yang terdapat di sekitar perkebunan salak, kurangnya perhatian masyarakat akan sanitasi lingkungan sekitar merupakan faktor penting dalam perkembangbiakan vektor malaria di daerah ini. Dengan sanitasi yang buruk dan tersedianya genangan air yang disukai nyamuk Anopheles meletakan telur mereka untuk berkembangbiak, maka akan meningkatkan populasi nyamuk di daerah ini.

\section{Multivariat}

Setelah dilakukan uji regresi logistik, diketahui bahwa hubungan variabel dengan kejadian Malaria yang berpengaruh atau besar adalah variabel keberadaan semak-semak ( $\mathrm{p}=0,000)$ yang disusul dengan varibel keberadaan langit-langit $(p=0,000)$, keberadaan parit/selokan $(p=0,005)$, keadaan dinding rumah $(\mathrm{p}=0,029)$, dan keadaan kawat kasa $(\mathrm{p}=$ 
0,032). Variabel yang paling berpengaruh yaitu kebiasaan keberadaan semak-semak dengan nilai $\mathrm{p}=$ 0,000 , dimana penelitian ini menggunakan derajat kepercayaan 95\%, dimana hubungan antar variabel dikatakan bermakna jika $\mathrm{p}<0,05$ dan tidak bermakna jika $\mathrm{p}>0,05$.

Dari hasil analisis tersebut meunjukan responden yang terdapat semak-semak di sekitr rumah memiliki peluang untuk bisa terkena penyakit Malaria dari pada responden yang tidak terdapat semak-semak di sekitr rumah Seharusnya semak-semak yang berada di sekitar rumah di musnahkan/dihilangkan sehingga kemungkinan terkena Malaria dapat dikurangi karena semak-semak dapat menjadi tempat perindukan nyamuk Anopheles.

\section{SIMPULAN DAN SARAN}

\section{Simpulan}

1. Ada hubungan yang bermakna antara keberadaan kawat kasadengan kejadian Malaria di Wilayah Kerja Puskesmas 1 Banjarmangu Kabupaten Banjarnegara Tahun 2016, karena nilai $\mathrm{p}=0,011$ $(\mathrm{p}<0,05)$

2. Ada hubungan yang bermakna antara keberadaan langit-langit rumah dengan kejadian Malaria di Wilayah Kerja Puskesmas 1 Banjarmangu Kabupaten Banjarnegara Tahun 2016, karena nilai $\mathrm{p}=0,000(\mathrm{p}<0,05)$

3. Tidak ada hubungan yang bermakna antara keadaan dinding rumah dengan kejadian Malaria di Wilayah Kerja Puskesmas 1 Banjarmangu Kabupaten Banjarmangu Tahun 2016, karena nilai $\mathrm{p}=0,743(\mathrm{p}>0,05)$

4. Ada hubungan yang bermakna antara keberadaan semak-semak rumah dengan kejadian Malaria di Wilayah Kerja Puskesmas 1 Banjarmangu Kabupaten Banjarnegara Tahun 2016, karena nilai $\mathrm{p}=0,000(\mathrm{p}<0,05)$

5. Ada hubungan yang bermakna antara keberadaan parit/selokan di sekitar rumah dengan kejadian Malaria di Wilayah Kerja Puskesmas 1 Banjarmangu Kabupaten Banjarnegara Tahun 2016, karena nilai $\mathrm{p}=0,000(\mathrm{p}<0,05)$

6. Tidak ada hubungan yang bermakna antara keberadaan kandang ternak di sekitar rumah dengan kejadian Malaria di Wilayah Kerja Puskesmas 1 Banjarmangu Kabupaten Banjarmangu Tahun 2016, karena nilai $\mathrm{p}=0,737$ $(\mathrm{p}>0,05)$

7. Tidak ada hubungan yang bermakna antara kebiasaan menggunakan kelambu dengan kejadian Malaria di Wilayah Kerja Puskesmas 1 Banjarmangu Kabupaten Banjarmangu Tahun 2016 , karena nilai $\mathrm{p}=0,072(\mathrm{p}>0,05)$
8. Ada hubungan yang bermakna antara kebiasaan menggunakan obat nyamuk dengan kejadian Malaria di Wilayah Kerja Puskesmas 1 Banjarmangu Kabupaten Banjarnegara Tahun 2016, karena nilai $\mathrm{p}=0,000(\mathrm{p}<0,05)$

9. Ada hubungan yang bermakna antara kebiasan keluar rumah malam hari dengan kejadian Malaria di Wilayah Kerja Puskesmas 1 Banjarmangu Kabupaten Banjarnegara Tahun 2016, karena nilai $\mathrm{p}=0,000(\mathrm{p}<0,05)$

10. Ada hubungan yang bermakna antara keberadaan genangan air di sekitar rumah dengan kejadian Malaria di Wilayah Kerja Puskesmas 1 Banjarmangu Kabupaten Banjarnegara Tahun 2016, karena nilai $\mathrm{p}=0,014(\mathrm{p}<0,05)$

11. Variabel hasil analisis multivariat menghasilkan variabel risiko yang berpengaruh besar terhadap kejadia penyakit Malaria di Wilayah Kerja Puskesmas 1 Banjarmangu Kabupaten Banjarnegara Tahun 2016 adalah keberadaan kawat kasa ( $\mathrm{p}=0,032$ ), keberadaan langit-langit rumah $(\mathrm{p}=0,000)$, keadaan dinding rumah $(\mathrm{p}=$ $0,029)$, keberadaan semak-semak ( $\mathrm{p}=0,000)$, keberadaan parit/selokan ( $\mathrm{p}=0,005$ ) dan yang paling berpengaruh adalah keberadaan semaksemak $(\mathrm{p}=0,000)$.

\section{Saran}

1. Bagi Instansi Kesehatan

a. Diperlukan adanya tambahan penyuluhan kesehatan bagi masyarakat khususnya tentang malaria. Hal ini dapat dilakukan melalui sosialisasi pada saat PKK, Posyandu, atau pada saat ke Puskesmas.

2. Bagi Masyarakat

a. Ventilasi yang ada di rumah hendaknya dipasang kawat kasa untuk menghindari masuknya nyamuk ke dalam rumah.

b. Rumah hendaknya dipasang langit-langit untuk mencegah masuknya nyamuk ke dalam rumah yang melalui celah atau lubang antara atap dengan dinding bagian atas.

c. Membersihkan semak-semak yang ada di sekitar rumah secara teratur.

3. Bagi Peneliti Berikutnya

Hasil penelitian ini dapat menjadi bahan referensi untuk melakukan penelitian tentang penyakit malaria. Karena pada dasarnya masih terdapat faktor lain yang menyebabkan kejadian penyakit malaria seperti perilaku pencegahan gigitan nyamuk, tingkat imunitas dan resistensi terhadap obat.

\section{UCAPAN TERIMA KASIH}

Terima kasih disampaikan kepada Puskesmas 1 Banjarmangu Kabupaten Banjarnegara, Dinas 
Kesehatan Kabupaten Banjarnegara dan Jurusan Kesehatan Lingkungan Politeknik Kesehatan Kementerian Kemenkes Semarang, sehingga penelitian dapat terselesaikan.

\section{DAFTAR PUSTAKA}

Akhsin Zulkoni, 2008, Manajemen Penyakit Berbasis Wilayah, Jakarta: UI Press.

Azwar A, 1996, Pengantar Ilmu Kesehatan Lingkungan, Jakarta: Mutiara Sumber Widya.

Barodji, 2000, Pemanfaatan hasil Survai Entomologi dalam Pemberantasan Malaria, disampaikan dalam seminar Hasil-hasil kegiatan SLPV Sulawesi Tengah, Palu.

Barodji, dkk., 2001, Bionomik vektor malaria di daerah endemis malaria Kecamatan Kokap, Kabupaten Kulonprogo,DIY, disampaikan dalam seminar Hari Nyamuk di UGM, Yogyakarta.

Barodji, dkk., 1993, Fauna Nyamuk di Daerah Se Luhir dan Se Belen, Kecamatan Wulanggitang, Kabupaten Flores Timur, Inpress.

Boesri H, dkk., 2003, Fauna Anopheles di daerah Kecamatan Borobudur, Kabupaten Magelang, Jawa Tengah, disampaikan dalam seminar Hari Nyamuk, Surabaya.

Darmadi, 2002, Hubungan Kondisi Fisik Rumah dan Lingkungan Sekitar Rumah serta Praktik Pencegahan dengan Kejadian Malaria di Desa Buaran Kecamatan Mayong Kabupaten Jepara. Semarang: FKM UNDIP.

Djamaluddin Ramlan dan Maisye Marlyn Kuhu, 2013, Penulisan Penelitian Eksplanatif, Purwokerto : Universitas Jenderal Soedirman.

Handayani L, dkk., Faktor Risiko Penularan Malaria Vivak, Berita Kedokteran Masyarakat. Vol. 24. No. 1. Maret 2008:38-43.

Handoko Riwidiko, 2007, Statistik Kesehatan, Yogyakarta : Mitra Cendikia.

Harijanto, dkk., 2010, Malaria dari Molekuler ke Klinis, Jakarta: Penerbit Buku Kedokteran EGC.

Iskandar A, Et all, 1985, Pemberantasan Serangga dan Binatang Pengganggu, Jakarta: Depkes RI.

Ika Nur Atikoh, 2014, Faktor yang Berhubungan dengan Kejadian Malaria di Desa Selakambang Kecamatan Kaligondang Kabupaten Purbalingga.

Lestari EW, 2007, Vektor Malaria di Daerah Bukit Menoreh, Purworejo, Jawa Tengah, Media Penelitian dan Pengembangan Kesehatan, Volume 17, No 1, hlm. 30-35.
Marcly L. Papilaya, dkk.,. 2012, Hubungan Antara Faktor Perilaku Dengan Kejadian Malaria Di Wilayah Kerja Puskesmas Remu Kota Sorong.

Pamela, AA, 2009, Hubungan Kondisi Fisik Rumah dan Lingkungan Sekitar Rumah dengan Kejadian Malaria di Desa Ketosari Kecamatan Bener Kabupaten Purworejo, Skripsi: Universitas Muhammadiyah Surakarta.

Prabowo, A, 2004, Malaria Mencegah dan Mengatasinya, Puspa Swara, Jakarta.

Aris Santjaka, 2013. Malaria Model Kausalitas. Yogyakarta: Nuha Medika.

Santy, Fitriangga, A., dan D. Natalia, 2014, Hubungan Faktor Individu dan Lingkungan dengan Kejadian Malaria di Desa Sungai Ayak 3 Kecamatan Belitang Hilir Kabupaten Sekadau. Jurnal Kedokteran Indonesia, Vol. 2, No.1, Hal. 265-272.

Soedarto, 2009, Penyakit Menular Di Indonesia, Jakata: Sagung Seto. . 2011, Malaria, Jakarta: Sagung Seto.

Umar Fahmi, 2008, Manajemen Penyakit Berbasis Wilayah, Jakarta: UI Press 